\title{
ニッケル基二元合金の耐熱に関する二三の研究
}

\author{
岡本 正三* 岡田千里*
}

\begin{abstract}
Masazô Okamoto, Senri Okada: Studies on the Heat-Resistant Properties of Nickel Solid Solution Binary Alloys. The paper presents data of solid solution hardening, work hardening recrystallization softening temperature and oxidation resistance for Ni-binary solid solution. The samples made from Mond nickel(99.85\%) with metallic additions of highest grades by means of a Tammann furnace melting were used for the above examinations, the results being as follows: (1) The alloying elements were as listed hereunder in order of decreasing potency of solidsolution hardening in water quenched alloys; $\mathrm{Ti}, \mathrm{Si}, \mathrm{Mo}, \mathrm{Al}, \mathrm{Mn}, \mathrm{Cr}, \mathrm{W}, \mathrm{Fe}, \mathrm{Cu}$ and $\mathrm{Co}$. (2) The solidsolution hardening is caused by the distortion of Ni-lattice, so that the greater the difference in atomic radius between the added element and $\mathrm{Ni}$, the greater the hardening effect. (3) The less the hardness of alloy before cold-working, the greater the work-hardening effect, that is, the larger the amount of the alloying element and the greater the difference in atomic radius between the added element and $\mathrm{Ni}$, the less the work-hardening effect. (4) In most cases the softening temperature is raised by the increase of the amount of alloying elements, especially by small amount of $\mathrm{Ti}$ - or Al-addition. The softening temperature is raised up to $800^{\circ}$ in the alloys with above $10 \%$ of $\mathrm{Mo}$, above $15 \%$ of $\mathrm{W}$ or above $18 \%$ of $\mathrm{Cr}$, while it is lowered by $\mathrm{Cu}$-addition. (5) The oxidation resistance is generally reduced by alloying elements, especially by $\mathrm{Fe}$ or $\mathrm{Mo}$, but $\mathrm{Cu}$ or $\mathrm{Si}$ scarcely affects it. In alloys with above $10 \%$ of $\mathrm{Cr}$ the oxidation resistance is extremely improved.
\end{abstract}

(Received May 12, 1957)

I. 緒 言

第二次世界大戦を契機として耐熱材料の目覚しい発展が あり, Ni 基合金についても注目すべき合金が現れるように なつた. Ni は元来その稀少性から使用が制限を受ける傾向 は強いが，Stellite 系の Co を主体とする耐熱材料と皎べ れば稀少性の程度は少く，将来の実用材料として大きな期 待をかけられているもの〉一つである.

今日各種の耐熱材料は実用面からすれば一応種類は出尽 した感があつて，目下はそれらの材料の基本的な事柄を新 しく振り返つてみようとするところに来ている. $\mathrm{Fe}$ 基二元 合金については，C. R. Austin(1)(2) は硬度の測定から Fe の $\boldsymbol{a}$ 固溶体で結晶の歪の大きいほど硬化は激しいと述べ, Fe の原子半径と固溶元素のそれとの差の大きいほど，それら 固溶元素の $\boldsymbol{\alpha}$ 固溶体に対する硬化作用は強く，また軟化温 度は $\mathrm{Mo}, \mathrm{Cr}, \mathrm{Mn}$ などの添加によつて上畀し，固溶範囲で のその上年度は添加元素濃度の少いときに激しく, 多くな るとさほど変化しなくなるとし，軟化温度に対して Ni, Co はあまり関倸がないとしたまな佐藤氏(3)为低炭素鋼の再 結晶軟化に和よぼす各種合金元素の影響を研究し, $\mathrm{Nb}, \mathrm{Ti}$, $\mathrm{Mo}, \mathrm{W}, \mathrm{V}, \mathrm{Cr}$ 特よび Coはその軟化温度を上䄯さすが, Ni, $\mathrm{Mn}, \mathrm{Si}, \mathrm{Al}, \mathrm{Sn}$ および P はあまり影響を与えないと述べて

* 東京工業大学金属工学教室

(1) C. R.Austin, Trans. ASM, 31(1943), 321.

(2) C. R. Austin, Trans. ASM, 35(1945), 446.

（3）佐藤，西沢，本田，鉄飞鋼，40(1954), 1115 .
いる. 一方, Ni 合金については C. E. Rausley 等(4)によつ て $\mathrm{Mn}, \mathrm{Mg}, \mathrm{Fe}$ との二元合金の細線で研究が行われ,これ らの添加がいずれも抗張力, 再結晶温度を著しく上昇さす と述べている.他の基礎的なことの詳細はな抔不明である. 本研究では耐熱合金として必要な諸特性のうちで, 再結晶 軟化性, 耐酸化性などを $\mathrm{Ni}$ 基の各種二元合金について詳細 に追求した．これが $\mathrm{Ni}$ 基実用合金の耐熱性を論ずる場 合 の参考となるであろろと考えて報告する次第である.

\section{II. 試料および実験方法}

試料の配合組成は Table 1 の通りで, 使用した Ni は純 Table 1. Nominal composition 度 $99.85 \%, 0.087 \%$ of specimens.

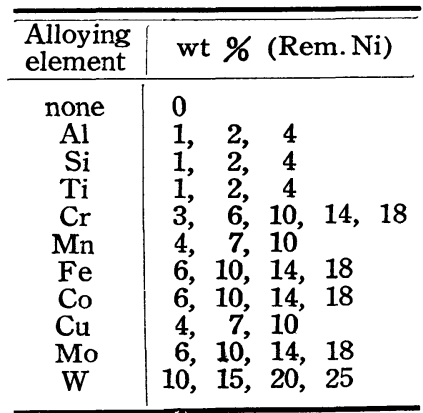
$\mathrm{C}, 0.006 \% \mathrm{~S}$ の mond nickel で, これに配合 する元素は総て単体金 属のま〉で添加した. とくに Cr, Ti, Si など の純度については注意 して, Crとしては英国 製純度 $99.4 \% \mathrm{Cr}$ を, Ti としては英国製 $99.5 \%$ のスポソヂ状

Tiを，また Si としては $98.7 \%$ 純度のものを使用した. 各

(4) C. E. Rausley \& C. J. Smithells, J. Inst. Metals, 49 (1932), 286. 
試料は $60 \mathrm{~g}$ とし，熔解はタンマン炬を用い，酸化を防ぐた め表面を水素で覆うようにして急速に熔解し， $1 \times 1 \mathrm{~cm}$ の 金型に鋳込九だ

次に均一化のため $1250^{\circ} 1 \mathrm{hr}$ 加熱後, $1250^{\circ}$ よ り厚さ減少率 $35 \%$ の鈮造を行い, 最後に $1000^{\circ}$ で $15 \mathrm{~min}$ 加熱後水冷し，これを標準状態とした。 まず磦準状態での硬度を Rockwell B で測定し， 次に常温で厚さ減少率 $28 \%$ の鍛造を行い,この 加工面の表面約 $0.5 \mathrm{~mm}$ を削り, 加工面で硬度測 定を行い, 以後 $500^{\circ}$ より $800^{\circ}$ の間で段階的に 30 $\min$ づつ加熱して各段階で加工面の硬度を測定し た. 次に耐酸化性を検討するため $1000^{\circ}$ に保つた ニクロム炉内の静止空気中 で $64 \mathrm{hr}$ まで繰返し加 熱し，途中時間に招いて空冷後粗布でこすつて落 しうる酸化膜を剥離させ, その時々の重量変化を 測定した.

\section{III. 結果とその考察}

標準状態の各試料の硬度と添加元素量との関係を Fig. 1 示す．同図より $\mathrm{Ti}, \mathrm{Si}$ などは少量で硬化作用著しく， $\mathrm{Cu}, \mathrm{Co}$ などの硬化作用は極く僅かであることがわかる.な 呿，この状態での顕徽鏡観察を行つたが，いずれも均一な 固溶体であつた. 粒度はすべてが著しく大きいが，特に

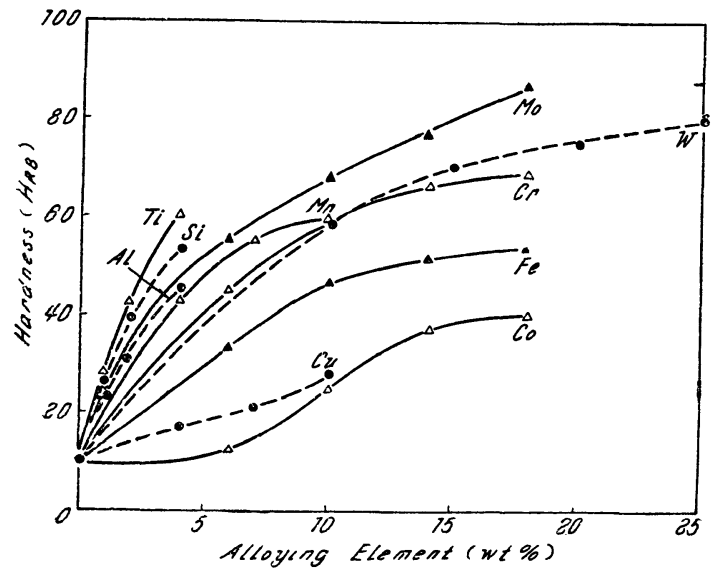

Fig. 1 Effect of alloying elements on the hardness of various binary alloys of nickel quenched from $1000^{\circ}$ into water.

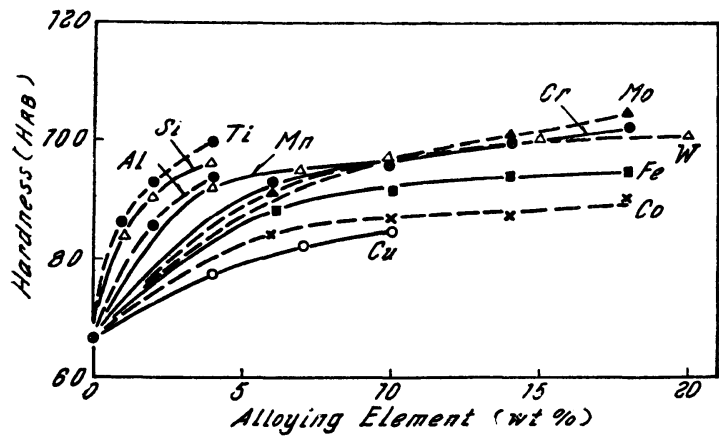

Fig. 2 Effect of alloying elements on the hardness of the alloys reduced $28 \%$ in thickness by cold hammering.
$\mathrm{Al}, \mathrm{Si}, \mathrm{Ti}$ 添加合金が粗大で 1 個の粒の平均直径が 0.5 一 $0.8 \mathrm{~mm}$ もあつた。他に顕著な特徵はみられなかつた。
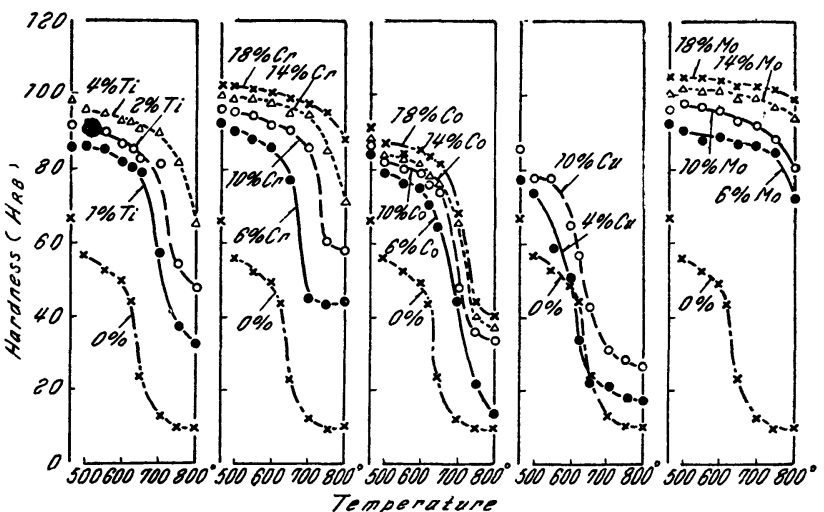

Fig. 3 Relation between reheating temperature and Rockwell $\mathrm{B}$ hardness for the alloys reduced $28 \%$ in thickness by cold hammering.

次に $28 \%$ 常温加工したときの硬度と添加元素との関係 をFig.2 亿示す．これを標準状態の Fig.1 と比較すると き, 各元素間の順序は殆んど同じであるが, 各元素相互の 差は少くなつている. 常温加工後加熱していつた場合の硬 度変化は一般厄添加量の增すほど軟化温度は上年し，とく に Mo, $\mathrm{Cr}, \mathrm{W}$ でその傾向が著しい. これに反し $\mathrm{Cu}$ では 軟化が非常に早くなる。こうした硬度变化の代表的なるの そして Ti, $\mathrm{Co}, \mathrm{Cu}, \mathrm{Mo}, \mathrm{Cr}$ をとれぞれ単独に添加した試料 そついての結果を Fig.3 に示した. な特 $\mathrm{Al}, \mathrm{Si}, \mathrm{Mn}, \mathrm{Fe}$ は $\mathrm{Ti}, \mathrm{Co}$ と類似して和り，W は $\mathrm{Mo}, \mathrm{Cr}$ と類似している ので省略した。

酸化実験に招ける試料の重量变化と時間との関係のうち 特徴的なるのを Fig.4 に示した. $\mathrm{Si}, \mathrm{Cu}$ の添加怢酸化重 量変化にさして影響を与兄ないが，一般に合金元素の添加 は耐酸化性を劣化する傾向があり，とく飞 $\mathrm{Mo}, \mathrm{Fe}$ の添加 がよくない.たよ゙し Crでは $10 \%$ 以下の添加が著しい悪影 響を扮よ淁すにもか子わらず，それ以上の添加では極めて 良好な耐酸化性を示すことが注目される。な特これら試料

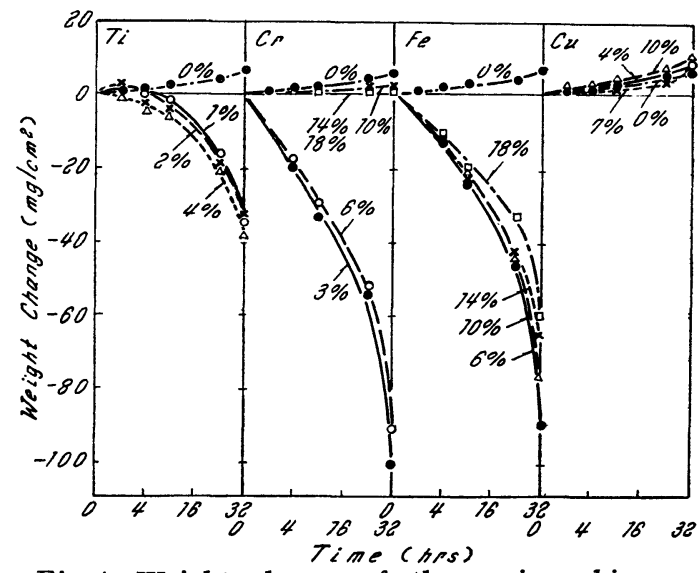

Fig. 4 Weight change of the various binary alloys heated in still air at $1000^{\circ}$. 
の $1000^{\circ} 64 \mathrm{hr}$ 加熱後の表面の酸化膜の状態は次の如くで ある。

純 $\mathrm{Ni}$ ：外層は黒灰色の $\mathrm{Ni}_{2} \mathrm{O}_{3}$ の如き緻密な層で内側に $\mathrm{NiO}$ らしい層.

$\mathrm{Al}$ 添加合金：黑灰色の緻密な $\mathrm{Al}_{2} \mathrm{O}_{3}+\mathrm{NiO}$ の如き酸化膜 が生ずるが，殆んど剥離.

$\mathrm{Si}$ 添加合金：灰色のつやのない酸化膜で，1\%,4\%の添 加では僅か剥離.

Ti 添加合金：つやのある黒色酸化膜殆んど剥離し，下層 に $\mathrm{NiO}$ らしい層.

$\mathrm{Cr}$ 添加合金：3\%，6\%では外側の黒灰色の酸化膜殆え ぞ剥離し，その下に綠色の層. $10 \%$ 以上添加ではつやの ない暗灰色の強固に密着した酸化膜.

$\mathrm{Mn}$ 添加合金：つやあるも粗い酸化膜，4\%では僅かに 剥離.

$\mathrm{Fe}$ 添加合金：表面の灰色酸化膜完 全に剝離 し，下は $\mathrm{Fe}_{2} \mathrm{O}_{3}$ の如き赤褐色層.

Co 添加合金：外層は暗灰色のつやある緻密な層,その下 に茶色の $\mathrm{Co}_{2} \mathrm{O}_{2}$ を混在すると思われる層. $6 \%$ では外層 の酸化膜殆んぞ剥離.

$\mathrm{Cu}$ 添加合金：すべての添加量で黒色のつやある 酸化膜 が密着.

Mo 添加合金：灰色酸化膜すべて剥離し,下層は綠色層.

$\mathrm{W}$ 添加合金：粗い灰色層僅か剥離し，下層は綠色層.

次に以上の結果を考察してみる．標準状態での各元素が その Ni 固溶体の硬度に蛙よぼす影響を考光るに, Fig. 1 の 各添加元素量を wt \% より at \% に換算すると, 各元素 の固溶体硬化の強さが違つて来るのは当然であるが，いま 添加量 $4 \%$ に招いての Ni 固溶体に対する硬化作用の強い ものより配列すると次の順序のようになる.すなわち wt \%では Ti, Si, Mo, Al, Mn, Cr, W, Fe, Cu, Co. また at \%ではW, Mo, Ti, Mn, Si, Cr, Al, Fe, $\mathrm{Cu}$, Co となる. この順序は加工やその後の再加熱によつ てあまり変化しない，添加元素が Ni に固溶するときは Ni の結晶格子に雨を与光，この歪の大きいほど硬化の程度が 大となる．この関係は Ni に第二元素が固溶したときの $\mathrm{Ni}$ の格子常数の変化(5) と, 本実験に扣忷る硬度変化とがほよ゙ 比例することより明らかである. Austin(1)は Fe 基二元固 溶体で $\mathrm{Fe}$ と原子半径の差の大きいもの汪ど硬化作用は強 く，また結晶構造の異るもの，和よび固溶限の少いものは 硬化作用が強いと主張している. ここに問題としている $\mathrm{Ni}$ 合金での関係はどうであろうか. いま各元素の原子直 径(6)，結晶構造(6)和よび际よその固溶限を緾めてみると，

Table 2 となる. 同表よりその原子直径が Ni のそれに近 い元素より配列すると, (Ni), Co, Cu, Fe, Cr, Mn, Mo, $\mathrm{W}, \mathrm{Al}, \mathrm{Ti}, \mathrm{Si}$ となる. いまこの順序で元素を横に配列し, 各 元素を $4 \mathrm{wt} \%$ 添加したときの標準状態 $\left(1000^{\circ} 15 \mathrm{~min}\right.$ 水

(5) T.H. Hazhett \& E. R. Parker, Trans. ASM, 46 (1954), 703.

（6）金属便覧による.

冷), 加工状態 $(28 \%$ 冷間加工), 加工後再加熱状態 $600^{\circ} 30 \mathrm{~min}$ ) の各状態での硬度を縦軸にとると Fig.5 なり, 添加元素の原子半径と合金の硬度との関係が見出さ れる. しかし硬度の順序は必ずしも規則的でない，その順 序を乱す因子としては,

Table 2 Crystal structure, atomic diameter and solid solubility of various alloying elements in nickel.

\begin{tabular}{|c|c|c|c|c|}
\hline \multirow{2}{*}{ Element } & \multirow{2}{*}{$\begin{array}{l}\text { Crystal } \\
\text { structure }\end{array}$} & \multirow{2}{*}{$\begin{array}{l}\text { Atomic } \\
\text { diameter } \\
\left(10^{-8} \mathrm{~cm}\right)\end{array}$} & \multicolumn{2}{|c|}{ Solubility at } \\
\hline & & & $\begin{array}{c}\text { Room } \\
\text { temperature }\end{array}$ & $600^{\circ}$ \\
\hline $\begin{array}{l}\mathrm{Al} \\
\mathrm{Si}\end{array}$ & $\begin{array}{l}\text { f.c.c. } \\
\text { diamond }\end{array}$ & $\begin{array}{l}3.16 \\
3.37\end{array}$ & $\underset{\|}{\text { uncertain }}$ & $\begin{array}{l}\sim 5 \% \\
\sim 5 \%\end{array}$ \\
\hline $\mathrm{Ti}$ & $\begin{array}{c}\text { c.p.h. } \\
\text { (other forms) }\end{array}$ & 3.23 & " & $\sim 4 \%$ \\
\hline $\mathrm{Cr}$ & $\begin{array}{l}\text { c.p.h. } \\
\text { b.c.c. }\end{array}$ & 2.84 & " & $\sim 35 \%$ \\
\hline $\mathrm{Mn}$ & $\begin{array}{c}\text { cubic } \\
\text { (other forms) }\end{array}$ & 2.87 & $\sim 10 \%$ & $\sim 30 \%$ \\
\hline $\mathrm{Fe}$ & (b.c.c. & 2.82 & $\begin{array}{c}\text { ordered } \\
\text { structure at } \\
14.4 \%\end{array}$ & $\sim 85 \%$ \\
\hline Co & $\begin{array}{l}\text { c. p. h. } \\
\text { f.c. c. }\end{array}$ & 2.80 & $100 \%$ & $100 \%$ \\
\hline$(\mathrm{Ni})$ & f.c. c. & 2.76 & $\overline{100}$ & - \\
\hline $\begin{array}{l}\mathrm{Cu} \\
\mathrm{Mo}\end{array}$ & $\begin{array}{l}\text { f.c.c. } \\
\text { b.c.c. }\end{array}$ & $\begin{array}{l}2.82 \\
3.10\end{array}$ & $\begin{array}{r}100 \% \\
\sim 18 \%\end{array}$ & $\begin{array}{r}100 \% \\
\sim 20 \%\end{array}$ \\
\hline W & b.c.c. & 3.12 & uncertain & $\sim 30 \%$ \\
\hline
\end{tabular}

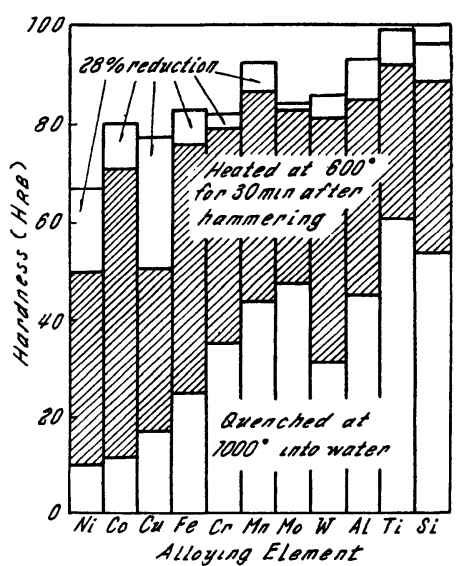

Fig. 5 Hardness of 4 wt \% alloy in the indicated treatment.
（1）非金属介在 物の存在すること があること、

(2) 結晶粒度の 相違することがあ ること,

(3) $\mathrm{Ni}$ 固溶体 は同じ結晶構造で あつても添加元素 の種類による結晶 構造の相違が何ん らかの影響を持つ と考它られる と,

（4）溶質原子は

固溶体内で統計的に均一に分布し，溶媒原子を置換してい るとみられるが，局部的には原子の偏在が可能とみられる こと；などが挙げられる.

冷間加工を施した時の加工硬化の割合を Fig.6亿示す. 同図は添加量の増すほど硬度增加が少く, Niの原子半径に 近い原子半径を持つ元素ほど加工硬化の割合が大きいこと を示して和り，結局加工硬化は加工前に持つている歪の少 いほど大きいといえる。

次に再結晶軟化であるが，いま便宜的に加工後の硬度と $1000^{\circ}$ 水冷の標準状態の硬度との丁度中間の硬度を示す再 加熱温度を再結晶軟化温度と仮定すると, 再結晶軟化温度 そ添加元素量との関係として Fig.7が得られる.一般に添 
加量の増すほど再結晶軟化温度は上昇する．Moでは $10 \%$ より，W は $15 \%$ よりまた Crでは $18 \%$ 以上で $800^{\circ}$ 以 上にも上畀した.たら゙し Cuでは軟化温度は一時低下し，ま た Mnは $7 \%$ に最高値がある.こうした再結晶軟化温度上 年の度合をみるに, 概して添加元素の原子半径と Ni のそれ との差の大きいものほど上年程度が大きい.かような再結 晶温度上年の原因は未だ解明されて水らず，また再結晶温 度と金属の融点とはほડ゙比例するとする説もあるが，これ も純金属ではたと竞てうした傾向はみられても合金につい ては全くそうした関係は見られない。

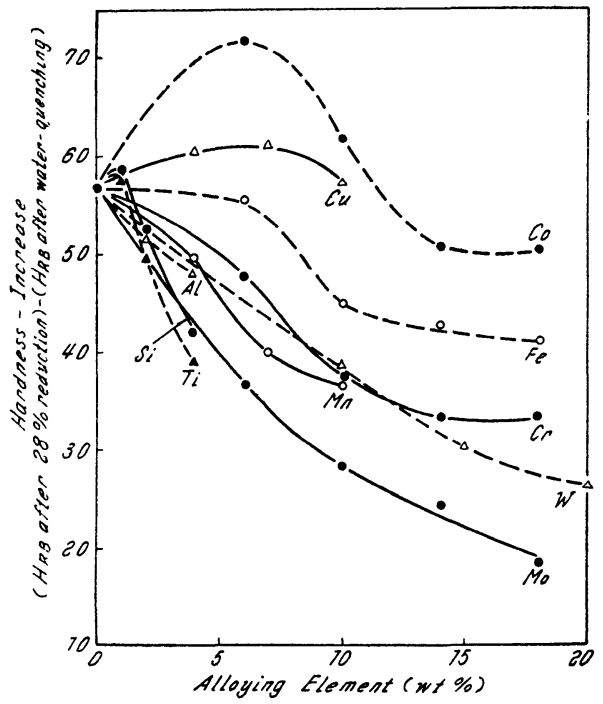

Fig. 6 Relation between alloying elements and hardness-increase after cold hammering of $28 \%$ reduction in thickness.

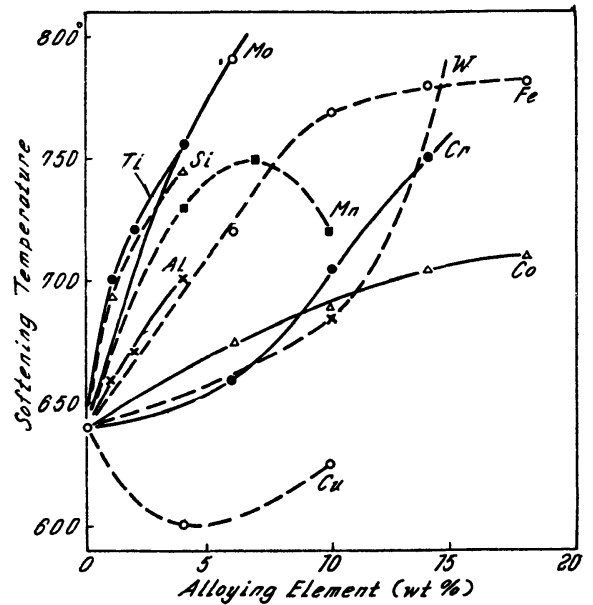

Fig.7 Effect of alloying elements on the recrystallization-softening-temperature after cold hammering of $28 \%$ reduction in thickness.

最後に酸化実験で $64 \mathrm{hr}$ 加熱後の重量変化量と添加元素 量との関倸を Fig.8に示した.重量減少を示す合金は増加 するものに較べ，その変化量が非常に多い．これは酸化膜 が合金に密着する場合にはそれが保護層となることを示す
ものである．一般に合金が酸化するときに生ずる酸化層の 組成は地合金の組成と異り，電陽性成分の方が電陰性成分

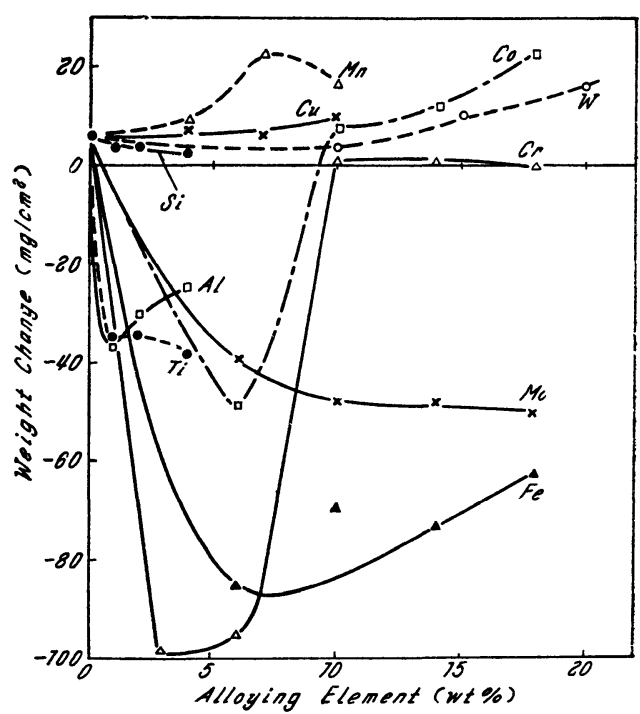

Fig8 The weight change of the various $\mathrm{Ni}$ binary alloys by heating at $1000^{\circ} 64 \mathrm{hrs}$.

よりも優先的に酸化すると考兄られている. 添加元 素が $\mathrm{Ni}$ より電陽性の場合には, その酸化層には合金元素の酸 化物がより多く混在し，それらが或る場合には緻密な保護 層を形成して，良好な耐酸化性を呈する。一方また，こう した酸化物と地合金との容積比が大となつて剥離し易い酸 化膜を生ずる場合もある. その他耐酸化性を左右する因子 として, 合金中への酸素の挔散速度, または酸化層中での金 属の拡散速度があり，これらの拡散速度の遅いときに良好 な耐酸化性を示すと考兄られる. またMo の添加で耐酸化 性が劣化する主な原因は，Mo 酸化物の融点が 790〜 795 と低いことに起因するとみられ，結局耐酸化性はこうした 多くの因子の相互作用によつて决定されるものである.

\section{IV. 結}

$\mathrm{Ni}$ 基二元固溶合金に括いて固溶体硬化，再結晶軟化温度 及び耐酸化性に及汸す各種添加元素の影響をしらべて次の 結論を得た。

(1) 合金元素の添加量を wt \%でとつて，固溶体の硬度 に及注す合金元素を硬化作用大なるものより示すと， $\mathbf{T i}$, Si, Mo, Al, Mn, Cr, W, Fe, Cu 特よび Co の順序になる.

(2) この硬化作用は添加元素が Ni の結晶格子に歪を与 えるため生ずるもので, 添加元素の硬化作用は Ni と添 加 元素との原子半径の差が大きいほど強い.

(3) 加工硬化する率は加工前の硬度の小さいほど大き い.すなわち，一般には添加元素量が増すほど加工硬化少 く, Ni と添加元素との原子半径の差が大きい合金ほど加工 硬化は少い傾向がある.

(4) 再結晶軟化温度は一般に添加元素量が増すと上梨し Moは $10 \%$ 以上で，W $\mathrm{W} 15 \%$ 以上で， $\mathrm{Cr}$ は $18 \%$ 以上 の添加でいずれも $800^{\circ}$ 以上にもなる. $\mathrm{Ti}, \mathrm{Al}$ も少量で站 
しく軟化温度を上げるが，Cu は一時低下させる。

(5) $1000^{\circ}$ の静止空気中での酸化に括いて, Cu, Si の添 加はさして影響を与えないが，一般に添加元素は耐酸化性 に悪影響を及ぼし，とくに Fe, Moの添加は悪い.たら゙し Cr $10 \%$ 以上の添加では極めて良好な耐酸化性を示すよ5
になる・

この研究は昭和 30 年度文部省耐熱材料研究班の 研究 の 一部として行つたもので，費用の援助を仰いだ文部省に感 謝すると共に，常に指導と鞭撻とをいただいた名大の武田 修三教授に厚くお礼を申上げます。 